\title{
UPAYA MENINGKATKAN NIAT BER WIRAUSAHA PEMUDA PEMUDI DI KECAMATAN DOLOK PANRIBUAN
}

\author{
Dian Gustrazaiman Purba Tambak ${ }^{1,}$ Toga Sehat Sehite ${ }^{2}$ \\ ${ }^{1,2)}$ Fakultas Ekonomi Universitas Simalungun Pematangsiantar \\ email: Dianpurbatambak26@gmail.com
}

\begin{abstract}
Abstrak
Setiap mahasiswa atau pemuda/pemudi di masyarakat, harus memiliki minat berwirausaha dan ketertarikan untuk membekali diri yang siap diterapkan setelah lulus kelak. Pengabdian ini untuk mengetahui cara meningkatkan minat berwirausaha pemuda/pemudi Kecamatan Dolok Panribuan Kabupaten Simalungun. Ada beberapa faktor yang mempengaruhi minat seseorang dalam berwirausaha yaitu 1. Berawal dari apa yang terjadi pada diri sendiri, 2. Berdasarkaan kesukaan 3. Melalui pengamatan yang berulang-ulang, 4. Melalui kegiatan sehari-hari, 5. Ditemukan karna dasar ketidaksengajaan. Hasilnya, bahwa materi pengabdian sangat membantu dalam peningkatan minat berwirausaha. Dari hasil pengabdian ini diharapkan nantinya akan ada tindak lanjut. Dari hasil yang di dapat bahwa pentingnya wirausahwan di pengaruhi oleh motivasi yang besar untuk pemuda/pemudi yang ada di Kecamatan Dolok Panribuan Kabupaten Simalungun.
\end{abstract}

Kata Kunci : UMKM, Wirausaha

\begin{abstract}
Every student or youth in the community, must have an interest in entrepreneurship and an interest in equipping themselves to be ready to be applied after graduation. This service is to find out how to increase interest in entrepreneurship for young people in Dolok Panribuan District, Simalungun Regency. There are several factors that influence a person's interest in entrepreneurship, namely 1. Starting from what happens to oneself, 2. Based on preferences 3. Through repeated observations, 4. Through daily activities, 5. Found because of accidental basis. The result is that the service material is very helpful in increasing interest in entrepreneurship. From the results of this service, it is hoped that there will be a follow-up. From the results obtained that the importance of entrepreneurship is influenced by great motivation for young people in Dolok Panribuan District, Simalungun Regency.
\end{abstract}

Keywords : UMKM, Entrepreneurs.

\section{PENDAHULUAN}

Wirausaha memainkan peran yang sangat penting dalam mempersiapkan generasi penerus bangsa yang berkualitas serta berdaya saing guna menghadapi berbagai tantangan dari perkembangan zaman. Kecamatan Dolok Panribuan merupakan salah satu daerah yang berada di Kabuapten Simalungun Propinsi sumatra utara, yang memiliki luas wilayah 154,30 km2. Memiliki jumlah penduduk sekitar 18,415 penduduk dengan bermata pencarian rata-rata petani.

Pada umumnya banyak terjadi pengganguran di dunia ini karena jumlah angkatan kerja yang saat ini tidak sebanding dengan jumlah angkatan kerja yang mampu menyaring atau berkeinginan menciptakan lapangan kerja untuk diri sendiri. Sebenarnya banyak keinginan jika seseorang mampu menciptakan lapangan kerja untuk dirinya sendiri dan akan berdampak positif juga untuk orang disekitarnya. Banyak lulusan perguruan tinggi yang belum mampu berwirausaha, sedangkan pada dasarnya berwirausaha dapat memberikan kemajuan kepasa diri sendiri. Semakin maju sebuah negara maka semakin banyak orang yang terdidik dan terlatih semakin banyak pula orang yang menganggur, maka semakin pntingnya dunia entrepreneur (wirausahawan). 
Pengangguran terjadi karena jumlah penawaran kesempatan kerja baik yang disediakan oleh pemerintah maupun swasta tidak sebanding dengan jumlah tenaga kerja yang ada saat ini. Cara mengatasinya adalah menciptakan lapangan kerja sendiri dengan menjadikan diri sebagai wirausahwana. Untuk menjadi seorang wirausahawan haruslah muncul minat dari diri sendiri. Minat itu muncul dikarenakan rasa keinginan, hobi dan munculnya akibat orang lain sukses berwirausaha. Menurut (Kasmir 2017:4), mengemukakan bahwa orientasi mahasiswa setelah lulus nantinya hanyalah untuk berkeinginan mencari kerja bukan memciptakan lapangan kerja sendiri. Rata-rata keinginan itu mucul mulai dari masukknya mereka ke universitas. Tidak diherankan jika pertumbuhan penggaguran semakin bertambah.

Untuk mampu berwirausaha dan membuka lapangan kerja sendiri, selain mempunyai skil semua mahasiswa juga harus mempunyai minat utuk berwirausahwan. Menurut Menurut Slameto (2013:180), "Minat adalah suatu rasa lebih suka dan rasa keterikatan pada suatu hal atau aktivitas, tanpa ada yang menyuruh". Dengan demikian minat memiliki pengaruh untuk melakukan apa yang menjadi keinginan pada obyek tertentu.

Minat berwirausaha akan mendorong seseorang untuk belajar dan membekali diri dengan berbagai ketrampilan berwirausaha sehingga mempunyai keberanian untuk membuka atau memulai usahanya dalam berbagai kesempatan. Itulah akhir pendidikan dalam lingkungan keluarga. Jadi, pendidikan dalam keluarga dimulai sejak anak lahir kedunia dari kandungan ibunya dan berhenti ketika anak meninggalkan keluarga asal untuk mendirikan keluarga baru. Pengalaman pendidikan dan pembelajaran dapat diperoleh dari berbagai lingkungan, bukan hanya dilingkungan sekolah, melainkan melalui masyarakat dan keluarga. Lingkungan masyarakat dan keluarga dapat memberikan pengalaman kewirausahaan ketika lingkungan tersebut merupakan sentra wirausaha.

\section{METODE}

Minat seseorang terhadap suatu objek akan lebih kelihatan apabila objek tersebut sesuai sasaran dan berkaitan dengan keinginan dan kebutuhan seseorang yang bersangkutan (Sardiman, 2015: 76). Apabila materi pekerjaan yang dikerjakan tidak sesuai dengan minat seseorang, maka seseorang tidak akan tertarik untuk bekerja dengan sebaik-baiknya. Ada beberapa faktor yang mempengaruhi minat seseorang dalam berwirausaha yaitu: 1. Berawal dari apa yang terjadi pada diri sendiri, 2. Berdasarkaan kesukaan 3. Melalui pengamatan yang berulang-ulang, 4. Melalui kegiatan sehari-hari, 5. Ditemukan karna dasar ketidaksengajaan.

\section{HASIL DAN PEMBAHASAN}

Dari kegiatan pengabdian dapat diketahui bahwa pemuda pemudi Kecamatan Dolok Panribuan telah dapat meningkatkan minat berwirausaha, arti penting berwirausaha dan mampu memilih dan mengangkat permasalahan menjadi wirausaha yang dapat diusulkan dalam pengabdian ini. Pengabdian masyarakat ini dilakukan untuk perbaikan berwirausaha. Masih ada beberapa pemuda pemudi yang pesimis dengan kegiatan wirausaha dalam mengatasi permasalahan yang muncul dalam proses perekonomian, khususnya pemuda pemudi yang tidak bekerja. Banyak permasalahan yang dimunculkan oleh pemuda pemudi yang tidak hanya memerlukan strategi perekonomian yang inovatif, akan tetapi juga memerlukan adanya dukungan dari pihak luar maupun pemerintah dan masyarakat serta perguruan tinggi, yang berkaitan dengan sarana-prasarana yang memadai yang digunakan untuk meminimalisasi permasalahan yang ada sehingga kesejahteraan pemuda pemudi akan dapat terus terjaga. Menyusun materi minat berwirausaha, Berdasarkan sikap dan pertanyaan yang diajukan dapat diketahui bahwa materi pengabdian sangat membantu dalam peningkatan minat berwirausaha. Dari hasil pengabdian ini diharapkan nantinya akan ada tindak lanjut. 


\section{SIMPULAN}

Kesimpulan Pelaksanaan pengabdian untuk pemuda/pemudi Kecamatan Dolok Panribuan dapat disimpulkan berhasil sampai tahap kemampuan untuk memilih dan menganggkat permasalahan menjadi topik dalam pengabdian dan analisis desa. Keberhasilan ini ditunjukkan antara lain oleh: Adanya kesesuaian materi dengan kebutuhan pengembangan, Adanya respon yang positif dari pemuda/pemudi, Pengabdian kewirausahaan merupakan salah satu unsur karya pengembangan kesejahteraan sehingga harus dibudayakan untuk dilaksanakan, kegiatan ini dilakukan untuk mengenalkan atau mempromosikan produk yang akan di pasarkan oleh Kabupaten Dolok Panribuan Kabupaten Simalungun.

\section{SARAN}

Hendaknya pemuda/pemudi Kecamatan Dolok Panribuan supaya tetap mempertahankan pemahaman dalam memilih dan menganggkat permasalahan serta mencari solusinya Pemuda/pemudi Kecamatan Dolok hilir diharapkan tetap mengedepankan pemahaman yang tepat pada kepentingan bersama. Pemuda/pemudi tetap bekerjasama dan berkoordinasi dalam kegiatan pemasaran.

\section{UCAPAN TERIMAKASIH}

Puji dan syukur kami panjatkan doa kepada Tuhan Yang Maha Esa karena berkatNya kami Dosen FE-USI dapat melaksanakan kegiatan pengabdian masyarakat dengan judul "UPAYA MENINGAKATKAN NIAT BER WIRAUSAHA PEMUDA PEMUDI DI KECAMATAN DOLOK PANRIBUAN".Kegiatan ini bermaksud meningkatkan niat wirausaha pemuda/pemudi di Kecamatan Dolok Hilir. Kegiatan ini dapat berjalan berkat adanya kerjasama yang baik antara pemerintah dan masyarakat setempat. Semoga kegiatan ini bermanfaat bagi Pemuda/Pemudi setempat.

\section{DAFTAR PUSTAKA}

Departemen Agama.(2008).Pedoman Pelaksanaan Pengabdian Kepada Masyarakat Perguruan Tinggi Agama Islam.Jakarta: DepartemenAgama.

Faizhol.Abdullah.(2015). Metode dan Teknik Kuliah Kerja NyataTransformatif.

Johnson.B. (2000). Toward A Multidimensional Model of Entrepreneurship: The Case of Kasmir. (2017). Kewirausahaan. Jakarta: PT.Rajagrafindo Persada.

Sardiman. Am.(2015). Interaksi dan Motivasi Belajar Mengajar.Jakarta:

Rajawali Pers.Slameto. (2013).Belajar dan Faktor-Faktor yang Mempengaruhinya. Jakarta: PT. Rineka Cipta. 